\title{
Orf in South Africa: Endemic but neglected
}

\author{
Authors: \\ Alessandra Scagliarini ${ }^{1}$ \\ Silvia Piovesana ${ }^{1}$ \\ Filippo Turrini ${ }^{1}$ \\ Federica Savini ${ }^{1}$ \\ Fortune Sithole ${ }^{2}$ \\ Cheryl M. McCrindle ${ }^{3}$ \\ Affiliations: \\ ${ }^{1}$ Dipartimento di Scienze \\ Mediche Veterinarie, \\ University of Bologna, Italy \\ ${ }^{2}$ Department of Paraclinical \\ Sciences, University of \\ Pretoria, South Africa \\ ${ }^{3}$ School of Health Systems \\ and Public Health, University \\ of Pretoria, South Africa \\ Correspondence to: \\ Alessandra Scagliarini \\ Email: \\ alessand.scagliarini@unibo.it \\ Postal address: \\ Dipartimento di Scienze \\ Mediche Veterinarie, \\ University of Bologna, Via \\ Tolara di sopra 50, 40064 \\ Ozzano Emilia, Bologna, Italy \\ Dates: \\ Received: 27 June 2012 \\ Accepted: 17 Oct. 2012 \\ Published: 07 Dec. 2012 \\ How to cite this article: \\ Scagliarini, A., Piovesana, \\ S., Turrini, F., Savini, F., \\ Sithole, F. \& McCrindle, C.M., \\ 2012, 'Orf in South Africa: \\ Endemic but neglected', \\ Onderstepoort Journal of \\ Veterinary Research 79(1), \\ Art. \#499, 8 pages. \\ http://dx.doi.org/10.4102/ \\ ojvr.v79i1.499
}

C 2012. The Authors. Licensee: AOSIS OpenJournals. This work is licensed under the Creative Commons Attribution License.
A survey amongst sheep and goat producers and veterinarians was undertaken to collect epidemiological data on orf in South Africa. Previous epidemiological studies on the presence of the disease in the country have not been documented and this report is the first descriptive epidemiological study of orf in South Africa. A seven-month investigation, realised by direct and indirect interviews and field observation, enabled us to outline incidence and risk factors of this disease and to better understand how the local farmers in rural areas relate to it. The results may contribute to better management of the disease in rural areas. By means of molecular analyses the phylogenetic relationships between field isolates from different areas have been identified. The findings gave a first important contribution to the general assessment of the economic impact of orf virus infections and the extent of the risk to human health.

\section{Introduction}

Orf virus (OV) is the type species within the genus Parapoxvirus (PPV) in the family Poxviridae, subfamily Chordopoxvirinae and it is the causal agent of a papular dermatitis affecting sheep, goats and occasionally other Artiodactyla species (Inoshima, Morooka \& Sentsui 2000; Kummeneje \& Krogsrud 1979). Typical OV lesions progress from erythema to macules, papules, vesicles, pustules and scabs, which are usually located around the mouth or nares of lambs and kids, on the teats of nursing ewes or around the coronets. The shed scabs contain high titres of stable virus, which, if kept dry, can remain infectious long enough to sustain annual outbreaks of the disease. Severe outbreaks of orf can occur in naïve flocks or herds, in which lesions are extensive and proliferative and do not spontaneously regress. The disease can be particularly severe in nursing lambs and kids where death from starvation and thirst can occur within days from lesions developing. During outbreaks, morbidity can approach $100 \%$, whilst mortality is usually less than $1 \%$. However, mortality can increase by $20 \%-50 \%$ as a result of secondary complications such as stress, immunosuppression or concomitant disease and can exceed $90 \%$ in the case of 'malignant orf' (Hosamani et al. 2009; Kitching 2004; Mazur \& Machado 1989; Scagliarini et al. 2006). The diagnosis is generally based on clinical signs, which are typical, but can be confused with those shown in other vesicular diseases of sheep and goats. These include foot and mouth disease (Watson 2004), bluetongue (Baipoledi, Nyange \& Hyera 2002), peste des petits ruminants (Rossiter \& Taylor 1994) and sheep and goat pox (Kitching 2004; Zheng et al. 2007), which are all listed by the World Organisation for Animal Health (OIE) as high-impact diseases. Other diseases that resemble orf include papillomatosis (Smith et al. 2002) and bacterial diseases such as staphylococcal dermatitis and dermatophilosis (Bath et al. 2011; Kitching 2004; Smith et al. 2002). Rapid and accurate differential diagnosis is therefore essential (McElroy \& Bassett 2007; Watson 2004), as early recognition of orf not only allows for institution of proper control measures and specific management strategies for unweaned animals, but also prevents zoonotic transfer.

Orf represents a zoonotic disease and an occupational hazard (Lederman et al. 2007; Steinhart 2005). In the United Kingdom it has been identified as the most frequent occupational zoonosis (Buchan 1996) and is also described as common in Australasia (Crumbie 1998). In addition to occupational exposure in veterinarians and dairy farm workers, it has been associated with religious slaughter (Ghislain, Dinet \& Delescluse 2001; Uzel et al. 2005). In humans, OV infections can cause painful lesions on the hands, fingers and face, which respond poorly to treatment and may take months to regress. Reports exist of atypical proliferating forms of giant orf in immunocompromised individuals, which can require hospitalisation (Rogers et al. 1989). Further complications such as erythema multiform, bullous pemphigoid, swan neck deformity, paresthesia and autoimmune blistering disorders have also been reported (Ara et al. 2008; Lederman et al. 2007; White et al. 2008). Although orf is often described as endemic, the actual prevalence of infections amongst livestock herds is greatly underestimated (Hosamani et al. 2009). The danger to consumers from unpasteurised milk is unknown; however, according to the Food and Agriculture Organization of the United Nations (FAO 2011) milk from diseased animals has to be discarded. This may have a negative impact on the profitability of dairy farms, particularly since the lesions remain for a 
long time and can cause mastitis. Studies on the economic implications of the disease have not been published despite it being regarded as one of the most important viral infections of sheep and goats in both developing (Perry et al. 2002) and developed countries (Haig \& McInnes 2002). According to the World Organisation for Animal Health, South Africa has more than 26 billion sheep and 5 billion goats (OIE 2010). Sheep are bred for wool as well as meat production. Angora goats are farmed for mohair and several indigenous breeds of goats for meat. There are also a number of goat breeds that are used for milk production in both commercial and informal sectors (Schoeman, Cloete \& Olivier 2010). Orf in sheep and goats is recognised in South Africa (Kitching 2004), but the epidemiology is not well documented. The aim of this investigation was to identify the risk factors and study the molecular epidemiology of orf in sheep and goats in South Africa.

\section{Materials and methods}

The study area comprised the whole sheep and goat farming sector in South Africa. This sector is highly dualistic and can typically be divided into communal farming and commercial farming. In South Africa, the majority of sheep are farmed commercially, whilst goats are more hardy and, except for Angora and dairy breeds, are typically encountered in small-scale farming and subsistence systems. Commercial sheep and goat farms are mainly found in the Eastern and Northern Cape, whilst in the rest of South Africa the majority of animals are owned by small-scale and communal farmers (Schoeman et al. 2010).

An extensive outbreak investigation was conducted over a period of seven months, from September 2009 to March 2010. The sampling methodology was based on two types of questionnaires, of which the first one was sent out by e-mail to all veterinarian members of both the South African Veterinary Association and the South African Society for Veterinary Epidemiology and Preventive Medicine. This questionnaire focused on awareness of the disease, the period of the year with the highest incidence, the species involved, and the age and the percentage of affected animals. An openended question was included at the end of the questionnaire to allow respondents to add more information on the disease.

The second questionnaire was addressed to local farmers and administered using structured interviews during field visits to rural areas where veterinarians had identified outbreaks. The statements were translated into the local languages with the assistance of animal health technicians working for the state veterinary services. Pictures of lesions in sheep and goats were shown to make the topics more understandable. The questionnaire focused on the awareness of the disease, time of the year with the highest incidence, age and percentage of animals affected, duration of the disease, localisation of the lesions, treatments and previous experience of transmission to humans. An accurate observation of the environment, animals, and breeding and management systems were undertaken in the areas where farmers were interviewed.

\section{Questionnaire data analysis}

Data obtained from the analysis of the questionnaires were recorded in a spreadsheet and subjected to qualitative statistical analyses using the Statistical Package for the Social Sciences (SPSS).

\section{Laboratory assays}

When suspected cases of orf were observed, scab samples from affected animals were collected using forceps and stored separately at $-20{ }^{\circ} \mathrm{C}$ in plastic bags or tubes until laboratory processing. In addition, scab samples were collected from cattle showing skin and mucosal lesions. The total DNA was extracted from the sampled scabs using the commercially available Nucleospin Tissue ${ }^{\circledR}$ kit (Machery and Nagel, Düren, Germany) according to the manufacturer's instruction. To assess the presence of OV, the DNA was used as template for a qualitative polymerase chain reaction (PCR) able to amplify a sequence of 594 nucleotides internal of the parapoxvirus-conserved gene B2L. Primers and

\begin{tabular}{|c|c|c|c|}
\hline Description & Country of origin & Host species & Reference \\
\hline AY424969 & USA & Musk ox & Guo et al. (2004) \\
\hline HQ239072 & Italy & Chamois & Scagliarini et al. (2011) \\
\hline HQ239073 & Italy & Ibex & Scagliarini et al. (2011) \\
\hline AY386263 & USA & Sheep & Delhon et al. (2004) \\
\hline AY453659 & Finland & Reindeer & Tikkanen et al. (2004) \\
\hline AB521167 & Japan & Serow & Inoshima et al. (2010) \\
\hline AB521165 & Japan & Serow & Inoshima et al. (2010) \\
\hline AB044796 & Japan & Serow & Inoshima et al. (2010) \\
\hline AY453666 & New Zealand & Sheep & Tikkanen et al. (2004) \\
\hline DQ904351 & Taiwan & Goat & Chan et al. (2007) \\
\hline HQ239071 & Italy & Chamois & Scagliarini et al. (2011) \\
\hline AY386264 & USA & Goat & Delhon et al. (2004) \\
\hline AY453654 & Germany & Sheep & Tikkanen et al. (2004) \\
\hline U06671 & New Zealand & Sheep & Sullivan et al. (1994) \\
\hline DQ263305 & India & Sheep & Hosamani et al. (2006) \\
\hline DQ263306 & India & Sheep & Hosamani et al. (2006) \\
\hline JN171856 & Germany & Cow & Dal Pozzo et al. (2011) \\
\hline GQ329670 & Germany & Human & Hautaniemi et al. (2010) \\
\hline GQ329669 & Finland & Reindeer & Hautaniemi et al. (2010) \\
\hline JN171852.1 & Italy & Cow & Dal Pozzo et al. (2011) \\
\hline AY453655 & New Zealand & Red deer & Tikkanen et al. (2004) \\
\hline HQ239068 & Italy & Red deer & Scagliarini et al. (2011) \\
\hline HQ239069 & Italy & Red deer & Scagliarini et al. (2011) \\
\hline JN162119.1 & Belgium & Cow & Dal Pozzo et al. (2011) \\
\hline AY453664 & Germany & Cow & Tikkanen et al. (2004) \\
\hline SA 52 & South Africa (NWP) & Sheep & This paper \\
\hline SA 88 & South Africa (LIM) & Boer goat & This paper \\
\hline SA 118 & South Africa (LIM) & Boer goat & This paper \\
\hline SA 85 & South Africa (LIM) & Cow & This paper \\
\hline SA 86 & South Africa (LIM) & Cow & This paper \\
\hline SA 87 & South Africa (GAU) & Boer goat & This paper \\
\hline SA 142 & South Africa (MPU) & Goat & This paper \\
\hline SA 90 & South Africa (WC) & Sheep & This paper \\
\hline SA 106 & South Africa (WC) & Boer goat & This paper \\
\hline SA 93 & South Africa (EC) & Boer goat & This paper \\
\hline SA 89 & South Africa (KZN) & Goat & This paper \\
\hline SA 126 & South Africa (NC) & Boer goat & This paper \\
\hline VAXSA & South Africa & OBP & This paper \\
\hline
\end{tabular}

Note: Please see the full reference list of the article, Scagliarini, A., Piovesana, S., Turrini, F. Savini, F., Sithole, F. \& McCrindle, C.M., 2012, 'Orf in South Africa: Endemic but neglected', Onderstepoort Journal of Veterinary Research 79(1), Art. \#499, 8 pages. http://dx.doi. org/10.4102/ojvr.v79i1.499, for more information.

EC, Eastern Cape; GAU, Gauteng; KZN, KwaZulu-Natal; LIM, Limpopo; MPU, Mpumalanga; NC, Northern Cape; NWP, North West Province; OBP, Onderstepoort Biological Products WC, Western Cape. 
cycling conditions were described previously (Inoshima et al. 2000). The OV vaccine strain (Orf freeze-dried vaccine Reg. No G1110 Act 36/1947, Onderstepoort Biological Products Ltd., Onderstepoort, South Africa) was used as a positive control and thus subjected to DNA extraction and PCR. PCR products representative of outbreak macro-areas as well as the orf vaccine produced by the Onderstepoort laboratory were sequenced and compared. Sequence analyses were performed by nucleotide and amino acid alignment according to the ClustalW method as implemented in the software MegAlign (DNAStar suite, Lasergene Inc., Madison). A phylogenetic tree was generated after ClustalW alignment with published sequences of parapoxviruses retrieved from GenBank (Table 1).

\section{Results}

\section{Field observations and analysis of questionnaires}

A total of 300 questionnaires were sent by email to members of the South African Veterinary Association and the South African Society for Veterinary Epidemiology and Preventive Medicine. Preliminary analysis showed that private veterinarians working exclusively with companion animals had never experienced cases of orf. The analysis thus focused on 80 questionnaires, from across the country, answered by 29 private and 51 state veterinarians. Amongst these, $84.3 \%$ of the state veterinarians and $58.6 \%$ of the private veterinarians confirmed to have experienced orf outbreaks. Of the veterinarians who had observed orf, $50 \%(n=30)$ stated that the disease mostly affected goats, $20 \%(n=12)$ had seen it mainly in sheep, whilst $26.7 \%(n=16)$ had observed it in both species. Regarding the time of the year in which outbreaks mainly occur, $50 \%$ of the veterinarians indicated the rainy season (from October to March), 13.3\% $(n=8)$ the dry season and $13.3 \%(n=8)$ reported the disease throughout the year. The majority of the veterinarians $(48.4 \% ; n=29)$ indicated a morbidity rate ranging from $1 \%$ to $20 \%$, whilst a minority $(8.3 \% ; n=5)$ estimated the morbidity rate to be higher than $40 \%$.

During the survey period, only one case of transmission to humans was reported. This was the result of a goat bite to a veterinarian, who developed a blister on her fingers and recovered three weeks after the onset of the lesion (Figure 1).

A total of 161 farms were visited, of which 106 were classified as 'rural' and 55 as 'commercial'. The data from structured interviews indicated that $75 \%(n=121)$ of farmers had prior knowledge about orf and that $90 \%(n=110)$ of them had experienced outbreaks within the last two years. Farmers reported that the disease lasts $2-3$ weeks $(33.6 \% ; n=37)$, 1 month $(43.6 \% ; n=48)$ and 2 months $(6.4 \% ; n=7)$, whilst $16.4 \%$ $(n=18)$ were unable to reply to this question. The majority of the farmers $(79.3 \% ; n=96)$ reported outbreaks during the rainy season, whilst $9.9 \%(n=12)$ observed a higher incidence of the disease during the dry season. The remaining $10.8 \%$ $(n=13)$ of respondents were unable to reply to this question.

Farmers were also interviewed about the age of affected animals: $80.2 \%(n=97)$ identified young animals (kids or lambs) as being more affected by orf virus, whilst $13.2 \%$ $(n=16)$ stated that the disease could occur in either young or adult animals. Only $3.3 \%$ of respondents $(n=4)$ observed the disease in adult animals only. Respondents consequently pointed out a correlation between disease occurrence and the lambing period, which was mostly concurrent. Distribution of the lesions was also recorded and the face was indicated as the most frequent site $(61.9 \% ; n=75)$. This localisation was often coupled with other sites, such as the ears $(14.9 \%$; $n=18)$, the legs $(10.7 \% ; n=13)$ and the udder $(6.7 \% ; n=8)$.

An association between the occurrence of the disease amongst flocks and the presence of thorny Acacia species, which grow and are browsed during the rainy season, was also observed.

With regard to traditional methods used by farmers to treat the disease, it was found that $61.8 \%(n=68)$ of the respondents treated sick animals during outbreaks, whilst 38.2\% $(n=42)$ did not. The most common recorded treatment consisted of application of Vaseline ${ }^{\circledR}$ oil (a registered skin product made of petroleum jelly) or machine oil. Copper sulphate and zinc preparations were also described. Farmers in rural areas scratch open the lesions by hand or using stones before treating them with oil when the disease is severe. Only a minority of farmers use antibiotics and seek veterinary assistance. In some rural communities in the North West province the disease is treated using the root of a plant called morototshwetshwe or sebete, which has been identified as Cassia italica (Table 2).

Less than $1 \%$ of the interviewed farmers used a commercial vaccine to prevent the disease, whilst the application of so-called auto-vaccination (using ground scabs applied to scarified skin) was reported by farmers from the Eastern and Northern Cape provinces and confirmed by local veterinarians.

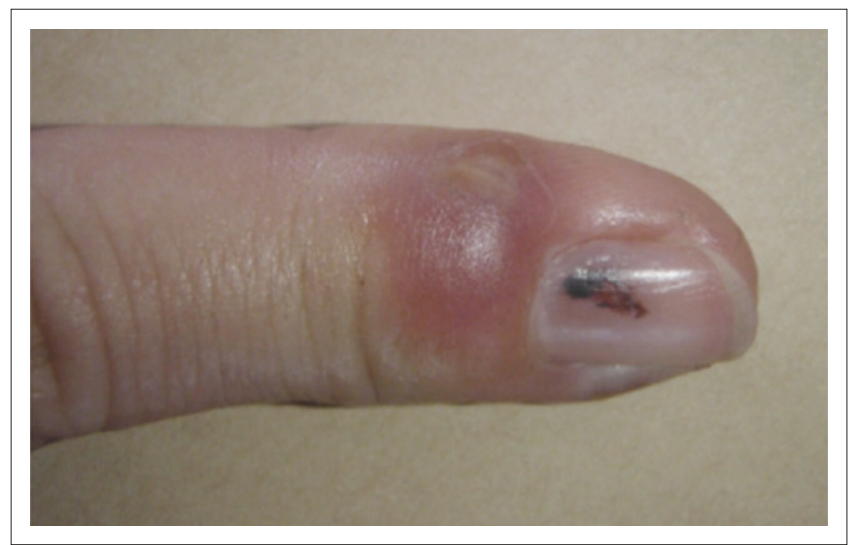

FIGURE 1: Human case of orf: Blistering lesion on a finger.

TABLE 2: Treatments or remedies for orf reported by farmers.

\begin{tabular}{lc}
\hline Treatment & Number of reports \\
\hline None & 42 \\
Oil & 36 \\
Zinc sulphate or copper sulphate & 10 \\
Antibiotic & 6 \\
Veterinary assistance & 7 \\
Plant decoction & 3 \\
Other homemade remedies & 6 \\
\hline Total & $\mathbf{1 1 0}$ \\
\hline
\end{tabular}




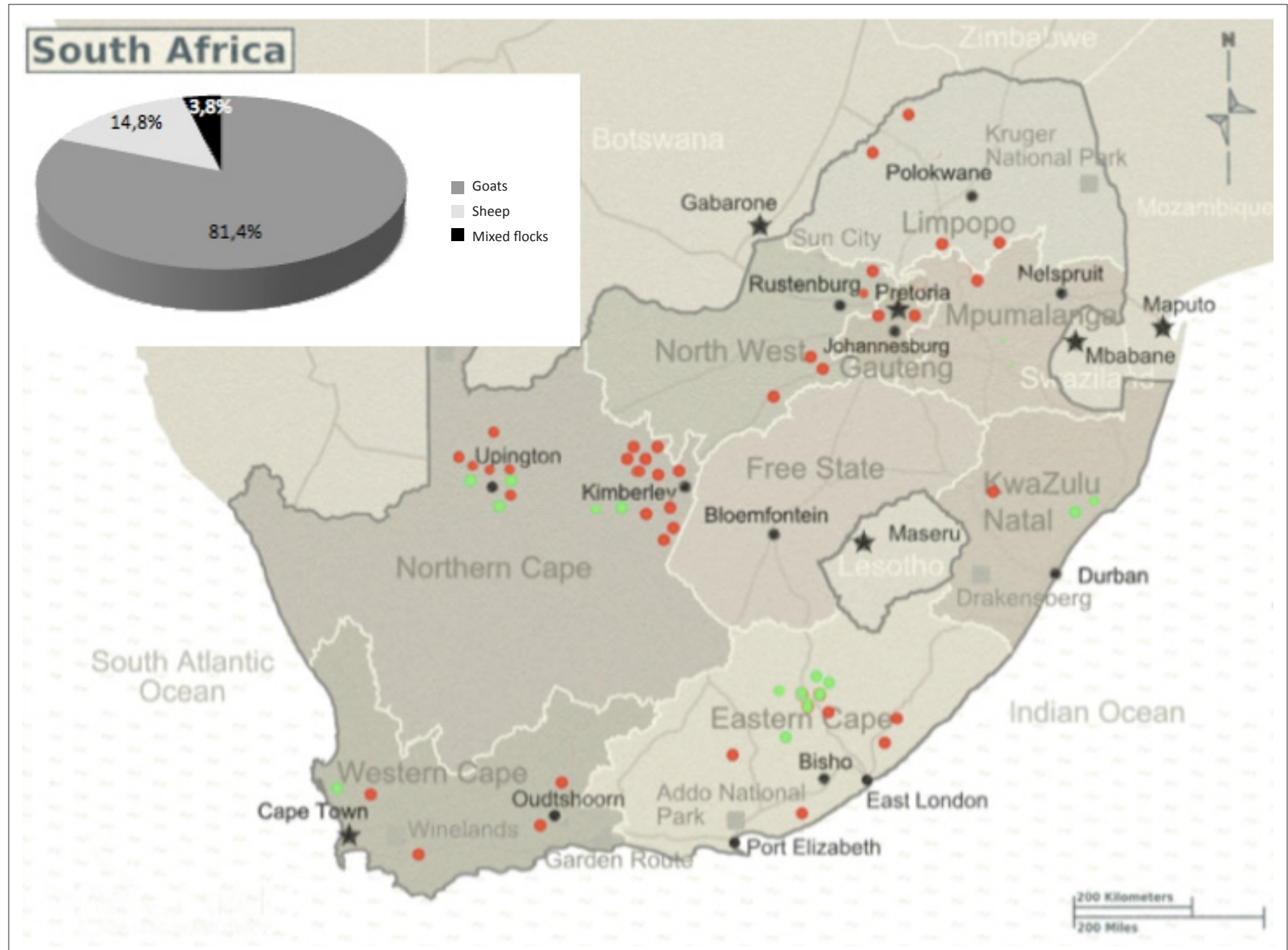

Red dots represent the outbreaks where pathological samples were collected during farm visits; green dots represent the distribution of the outbreaks reported by veterinarians. FIGURE 2: Map of the outbreaks (September 2009 - March 2010) and animal species involved.

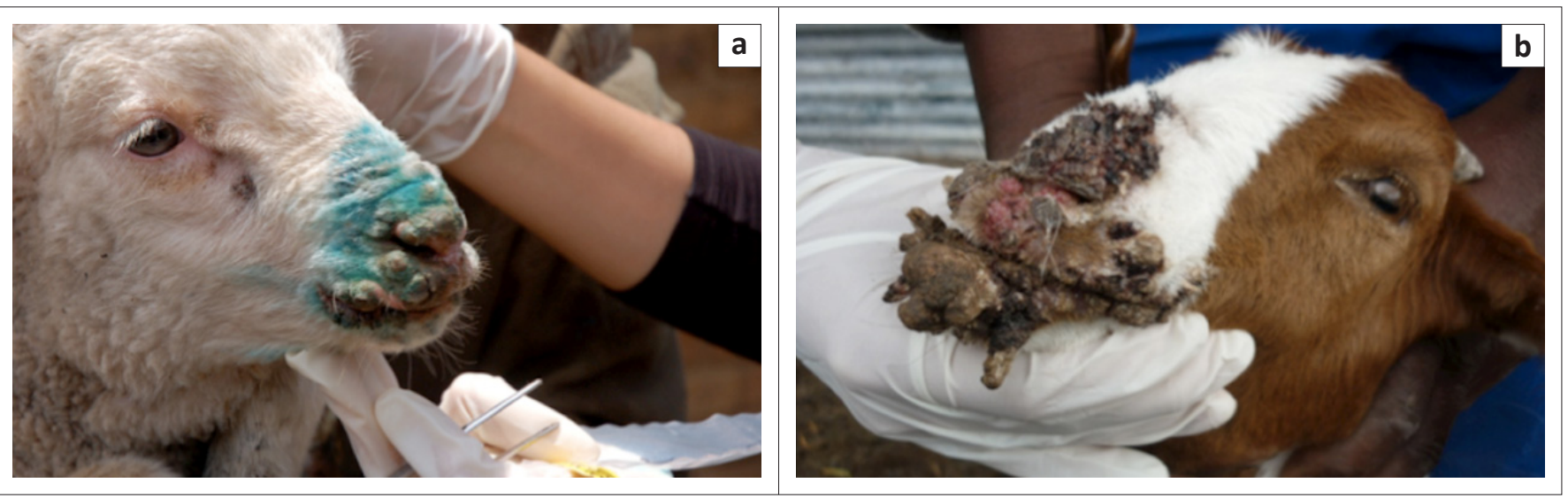

FIGURE 3: (a) Typical clinical case of orf virus infection in a sheep (sample A52); (b) Proliferative orf lesions in a Boer goat (sample A93).

\section{Spatial and temporal distribution of outbreaks}

During the period of investigation, 54 outbreaks of orf-like diseases amongst sheep and goats were reported. Of these, 44 occurred in rural areas and the rest on commercial farms. A total of 39 outbreaks of suspected parapoxvirus infections were visited and scab samples were collected for subsequent analysis. In addition, state veterinarians reported a further 15 outbreaks via email or phone, but these were neither visited nor sampled owing to logistical constraints. The majority of the outbreaks occurred in goat flocks and orf incidence appeared to be directly related to the sheep and goat populations of the provinces (Figure 2). In the investigated outbreaks, different degrees of severity of the disease were recorded, although it appeared that clinical signs seen in sheep were milder than in goats (Figure $3 a$ and $3 b$ ). 


\section{Diagnosis and genomic characterisation}

The diagnostic PCR performed on the DNA extracted from the scabs collected from diseased animals confirmed parapoxvirus infection through the amplification of a specific 594 base pair fragment of the B2L gene. The nucleotide sequences of the amplified products confirmed, in all cases, $\mathrm{OV}$ as the causative agent in sheep and goats. The residue identity of $B 2 L$ sequences ranged from $96.9 \%$ to $100 \%$ and from $97.5 \%$ to $100 \%$ at the nucleotide and amino acid level, respectively. A 100\% identity has been shown between field strains SA52, isolated from sheep in the North West province, A90 collected from sheep in the Western Cape, SA142 isolated from goats in Mpumalanga and the vaccine strain used in South Africa. A complete identity was also found between strains SA88 and SA106, isolated from goats in Limpopo and the Western Cape, respectively, and strains isolated from goats in KwaZulu-Natal (SA89), Gauteng (SA87), Limpopo (SA118), the Eastern Cape (SA93) and the Northern Cape (SA126). The PCR and subsequent sequencing performed on the DNA extracted from the scabs collected from cattle in two mixed herds in Limpopo allowed us to demonstrate pseudocowpox virus (PCPV). The two identified PCPV strains (SA85 and SA86) showed an identity of 99.3\% and $99.4 \%$ at nucleotide and amino acid level, respectively, leading us to conclude that the disease in cattle was not caused by a unique virus.

\section{Discussion}

Although it is generally accepted that orf is endemic in South Africa, the extent of the problem is unknown. The fact that 54 outbreaks occurred during the observation period in the whole study area indicated that the prevalence and the economic impact of the disease are probably underestimated by the veterinary profession. This can be due to the fact that only a limited number of farmers report outbreaks or seek veterinary assistance (Table 2). It is postulated that the underestimation of the importance of orf can be attributed to the fact that it is not a controlled or notifiable disease. As a result there is little or no data recorded by the veterinary authorities and no surveillance programmes on $\mathrm{OV}$ are running in South Africa. However, vaccine is produced and animal health technicians are consulted to collect samples when farmers suspect the presence of a more serious disorder such as foot and mouth disease or bluetongue.

Commercial breeders are often assisted by private veterinarians for specific cases only and so do not form part of routine surveillance. Consequently, private veterinarians report that the highest incidence is in sheep, which are farmed for wool and meat on commercial farms. In contrast, goats, which are known for their adaptability and fertility and browse in thornbush areas (Malan 2000), are mainly found in the informal rural sector. Thus, according to state veterinarians, who work in rural areas, goats are mainly involved in outbreaks.

According to the answers from the questionnaires, the morbidity of the disease observed by veterinarians $(1 \%-20 \%)$, was far lower than that observed during the field outbreaks we have inspected, where between $90 \%$ and $100 \%$ of animals in a flock showed clinical signs.

Our observations lead us to confirm that goats rather than sheep are mainly affected, which is in agreement with reports by veterinarians. The largest number of affected animals were Boer goats. According to existing reports (e.g. De La Concha-Bermejillo et al. 2003; Guo et al. 2003; Ndikuwera 1992) as well as our own observations, Boer goats appear to be more prone to developing severe OV infection (Figure 3b), which seriously impacts animal welfare and consequently the farming economy.

The majority of veterinarians, as well as the farmers, agreed that OV infections have a higher incidence during the rainy season (summer). This indication substantially differs from the epidemiological data observed in other countries, where the highest incidence has been reported in the dry season, when the consumption of dried, fibrous grass contributes to oral lesions and virus penetration (Lewis 1996; Rodríguez et al. 2011).

Environmental observation indicated that many plant species belonging to the Acacia genus were associated with the incidence of orf. These species are the dominant woody plants in the bushveld areas of South Africa. They produce spiked or hooked thorns and tender, succulent leaves early in the rainy season, which probably cause micro-lesions around the lips and faces of browsing goats. The virus enters through damaged mucosa and the scabs of an infected animal remain on the thorns, which can affect another animal. Sheep are grazers rather than browsers, although they also eat smaller thorn bushes.

Considering the seasonal and self-limiting nature of orf, the apparent low mortality (according to farmers) and short immunity conferred, it was not surprising that less than $1 \%$ of the farmers reported using commercial vaccines to prevent the diseases; instead they use homemade vaccines produced from scabs of sick animals. This procedure constitutes a further risk for transmission, as the scabs produced after vaccination contain live virus, which can survive in the environment for long periods (Nettleton et al. 1996). Furthermore, scratching the scabs off infected animals to produce the homemade vaccine, as well as treating them with oil, is considered a risk factor for zoonotic transmission to farmers. During our investigation, we were able to collect ethnoveterinary information such as traditional remedies to cure orf. In particular, we found that some farmers treated animals with a decoction of the roots of $C$. italica, both topically and orally and it was claimed that the remedy resulted in recovery from the disease within a few days. Previous reports have demonstrated the antimicrobial, anti-inflammatory, antipyretic, analgaesic, purgative and antitumor activity of C. italica (Assane et al. 1994; Jain et al. 1997; Kazmi et al. 1994; Masoko et al. 2010). At present there is no information about the antiviral properties of C. italica extracts and further studies will be needed to confirm this property. 
Orf shares clinical manifestations with other notifiable vesicular diseases of ruminants, such as bluetongue and foot and mouth disease. It was hypothesised that veterinarians operating in the provinces with a higher risk of foot and mouth disease might have a better knowledge of OV owing to regular surveillance and monitoring in flocks and herds. This hypothesis was, however, not confirmed, as our data showed no significant difference in the knowledge level with respect to province ( $p=0.076)$. During the study period, outbreaks of both bluetongue and foot and mouth disease occurred in South Africa, underlining the importance of a rapid differential diagnosis.

PCR is currently the most affordable and rapid method for the direct diagnosis of orf and also represents the preliminary step for genomic characterisation. The sequence of the PPV B2L gene, a homologue of the major envelope antigen, p37K, of the vaccinia virus, has been widely used as a molecular target for virus detection and diagnosis of infection and for identification of species within the genus Parapoxvirus (Inoshima et al. 2010). The molecular characterisation based on the partial nucleotide and amino acid sequences of representative strains of all the identified outbreaks (Table 2), showed a high level of conservation of the B2L gene. Previous reports observed mutations within the $B 2 L$ gene sequence of OV strains originating from the same outbreak (Abrahao et al. 2009; Chan et al. 2007; Guo et al. 2004; Hosamani et al. 2006; Klein \& Tryland 2005). Our results lead us to conclude that diseased sheep and goats were all affected with OV, whilst samples collected from cattle were shown to be positive for PCPV, leading us to promptly exclude other look-alike vesicular diseases in the investigated flocks. Pseudocowpox was already reported in South Africa in poorly managed farms, where it causes economic losses because of reduced milk production (Munz \& Dumbell 2004).

Our analyses allowed us to exclude a phylogenetic clustering linked to the geographical origin. In particular, we showed that strains SA52, SA90 and SA142 collected from the North West, Western Cape and Mpumalanga provinces clustered together. These strains were also found to be identical to the OV strain contained in the locally produced vaccine (Figure 4). Vaccination against $\mathrm{OV}$ results in scabby lesions as in naturally infected animals. Scabs that are formed are rich in virus, which, when shed, contribute to the environmental pool of the virus and can be the cause of further outbreaks. However, since the vaccine had never been used on the farms where samples were collected, the vaccine strain could be excluded as the causative agent of the outbreaks. On the contrary, the complete identity of several field strains with the vaccine strain seems to indicate that these viruses have been circulating over a long period of time. The phylogenetic analysis inferred from $B 2 L$ amino acid alignment confirmed the presence of a limited number of OV variants circulating in the country (Figure 4). This hypothesis seems to be further supported by the phylogenetic analyses inferred from the data of the concatenated alignment of three OV protein sequences, which allowed the identification of two clusters corresponding to the two main variants circulating in the country (data not shown). The limited movements of breeding animals within South Africa and a high level of adaptation of the OV to its host may represent a possible explanation for our observation.

The effects of zoonotic infections on human health are usually greatest on livestock keepers who live in close proximity to their animals. Approximately $46 \%$ of South Africans still live in rural areas, coming regularly into close contact with farm animals. For this reason it is remarkable that, in spite of a widespread presence of the disease in farmed animals, neither farmers nor veterinarians reported cases of orf infection in humans. OV infections in humans are consequent to the handling of infected animals or animal by-products or vaccination. For this reason, farmers, abattoir workers, veterinarians and shearers are at greatest risk of infection. During our investigation only one human case was confirmed (in a veterinarian) in September 2010. She was working in KwaZulu-Natal and became infected during foot and mouth disease surveillance whilst inspecting a goat with vesicular lesions in its mouth.

The demonstration that PCPV is circulating amongst cattle suggests that there are, indeed, further sources for parapoxvirus transmission to humans in South Africa.

Although PCPV and OV have already been identified as a cause of zoonotic diseases in South African veterinarians (Gummow 2003), parapoxvirus infections can be classified as a neglected zoonosis, as they are likely to be under-recognised

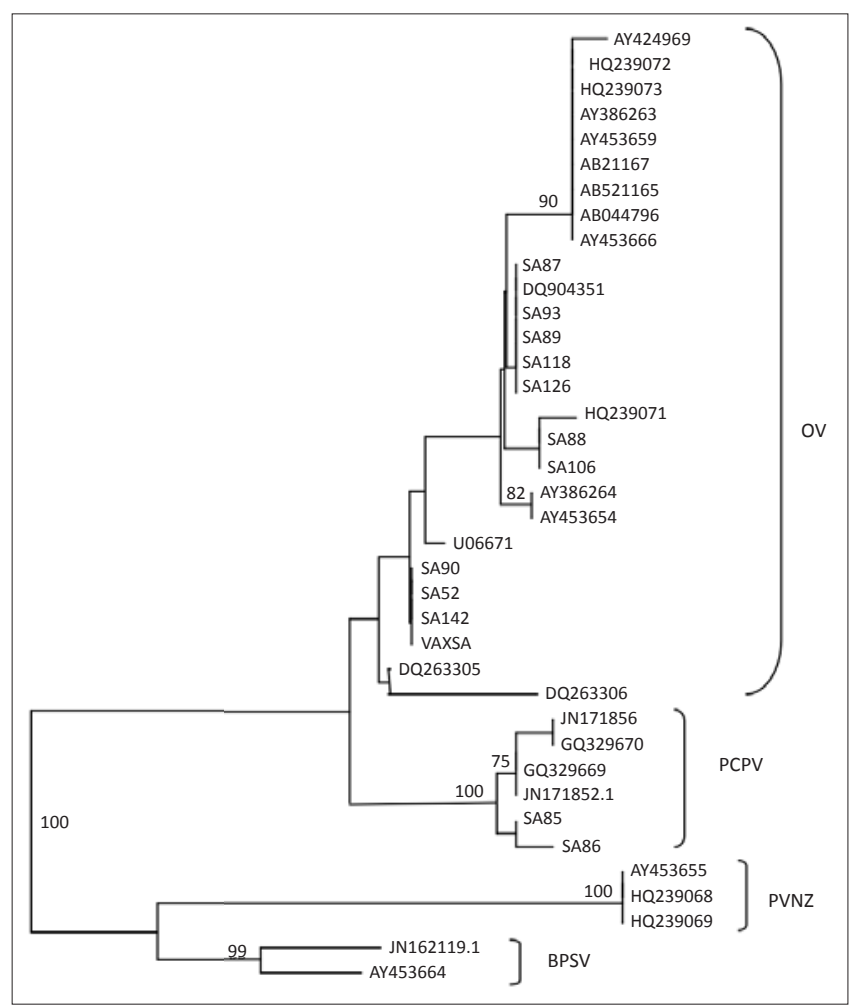

The evolutionary distances were computed using the JTT matrix-based method (Jones, Taylor \& Thornton 1992). The rate variation amongst sites was modelled with a gamma distribution. Numbers on the nodes show the bootstrap percentage calculated for 500 replicates. Evolutionary analyses were conducted with MEGA 5 (Tamura et al. 2011).

FIGURE 4: Phylogenetic tree generated using the neighbour-joining method (Saitou \& Nei 1987) after ClustalW alignment of the amino acid sequences of the major envelope protein encoded by the $B 2 L$ gene segment. 
by medical practitioners. OV and PCPV normally cause painful lesions on the hands, fingers and face, and in several cases lymphadenopathy is recorded, which is difficult to differentiate from other distal upper extremity entities such as sporothricosis, Mycobacterium marinum and leishmaniosis (Schmidt et al. 2006). It also shares risk factors and clinical features with other life-threatening diseases such as localised orthopox virus infections, tularaemia and anthrax (LewisJones 2004); missed or mistaken diagnosis constitutes ground for reflection on the sometimes incapacitating consequences of the disease on certain categories of patients, such as children and immunocompromised individuals (Lederman et al. 2007). Considering that South Africa has one of the highest incidences of HIV and AIDS in the world, with an estimated 5.6 million people infected in 2009, it is possible that cases of giant ulcerative and recurrent forms may be misdiagnosed and not recognised, whilst a correct diagnosis would allow physicians to formulate appropriate therapy and management.

\section{Conclusion}

In conclusion, the study design of this work was based on an investigation performed on natural outbreaks of orf in sheep and goats in South Africa. In line with classic epidemiology, disease determinants linked to the host, agent and environment and their interactions were described, providing the first descriptive epidemiological data on orf outbreaks in South Africa. Questionnaire responses from veterinarians and farmers have led to a better understanding of the host range, seasonal distribution of cases and environmental risk factors. A comparison between the actual number of outbreaks observed and the opinions of veterinarians on the likely incidence of orf suggests that the incidence of the disease is underestimated in South Africa. Our investigation led us to identify PCPV strains circulating in the cattle population, suggesting the necessity to collect more epidemiological data on parapoxvirus infections resembling vesicular diseases, also in bovines.

Although only one human case was reported during the observation period, the risk of zoonotic transmission, especially in low-income rural areas, is likely to be far higher, if based on the diagnosed human cases in other countries with similar levels of orf in livestock.

\section{Acknowledgement}

The authors wish to thank Prof. Kobus Eloff for his support in identifying the medicinal plant used to treat orf in the field and Dr Laura Gallina for her technical support in genomic sequencing.

\section{Competing interests}

The authors declare that they have no financial or personal relationship(s) that may have inappropriately influenced them in writing this paper.

\section{Authors' contributions}

A.S. (University of Bologna) was responsible for the project design. S.P. (University of Bologna) performed the field survey and collected samples. F.T. (University of Bologna) performed most of the laboratory experiments. F.S. (University of Bologna) contributed to the manuscript drafting. F.S. (University of Pretoria) made conceptual contributions and was responsible for critical review of the manuscript. C.M.M. (University of Pretoria) was the project leader.

\section{References}

Abrahao, J.S., Campos, R.K., Trindade, G.S., Guedes, M.I., Lobato, Z.I, Mazur, C. et al., 2009 , 'Detection and phylogenetic analysis of orf virus from sheep in Brazil: A case report', Virology 6, 47. http://dx.doi.org/10.1186/1743-422X-6-47

Ara, M., Zaballos, P., Sánchez, M., Querol, I., Zubiri, M.L., Simal, E. et al., 2008, 'Giant and recurrent orf virus infection in a renal transplant recipient treated with imiquimod', Journal of the American Academy of Dermatology 58(2 Suppl.), S39S40. http://dx.doi.org/10.1016/j.jaad.2006.04.027, PMid:18191701

Assane, M., Nydyema, R., Bassene, E., Sere, A. \& Gaye, O., 1994, 'Purgative activity of Cassia italica', Dakar Medicine 39(2), 125-128. PMid: 8654166

Baipoledi, E.K., Nyange, J.F.C. \& Hyera, J.M.K., 2002, 'A severe case of contagious ecthyma in Tswana goats', Journal of South African Veterinary Association 73(2), 86-87. PMid: 12240778

Bath, G.F, Janse van Rensburg, A., Pettey, K.P., Van Vuuren, M. \& Kidanemariam, A., 2011, 'A literature review and investigation of staphylococcal necrotic dermatitis in sheep', Journal of the South African Veterinary Association 82(4), 227-231. PMid:22616437

Buchan, J., 1996, 'Characteristics of orf in a farming community in mid-Wales', British Medical Journal 313, 203-204. http://dx.doi.org/10.1136/bmj.313.7051.203

Chan, K.W., Lin, J.W., Lee, S.H., Liao, C.J., Tsai, M.C., Hsu, W.L. et al., 2007, 'Identification and phylogenetic analysis of orf virus from goats in Taiwan', Virus Genes 35, 705712. http://dx.doi.org/10.1007/s11262-007-0144-6

Crumbie, A., 1998, 'The orf virus: A disease of the farming community', Community Nurse 4, 44-45. PMid:9763971

Dal Pozzo, F., Martinelle, L., Gallina, L., Mast, J., Sarradin, P., Thiry, E. et al., 2011 'Original findings associated with two cases of bovine papular stomatitis', Journal of Clinical Microbiology 49(12), 4397-4400. http://dx.doi.org/10.1128/ JCM.05281-11

De La Concha-Bermejillo, A., Guo, J., Zhang, Z. \& Waldron, D., 2003, 'Severe persistent orf in young goats', Journal of Veterinary Diagnostic Investigation 15, 423-431. http://dx.doi.org/10.1177/104063870301500504

Delhon, G., Tulman, E.R., Afonso, C.L., Lu, Z., De La Concha-Bermejillo, A., Lehmkuhl, H.D. et al., 2004, 'Genomes of the parapoxviruses ORF virus and bovine papular stomatitis virus', Journal of Virology $78,168-177$. http://dx.doi.org/10.1128/ JVI.78.1.168-177.2004

FAO Animal Production and Health and International Dairy Federation, 2011, Guide to good farming practice, viewed 12 June 2012, from http://www.fao.org/ docrep/014/ba0027e/ba0027e00.pdf

Ghislain, P.D., Dinet, Y. \& Delescluse, J., 2001, Orf en milieu urbain et coutumes religieuses [Orf in urban surroundings and religious practices: A study over a 3-year period]. Annales de Dermatologie et de Vénéréologie 128(8), 889-892. $\mathrm{http}: / / \mathrm{dx}$.doi.org/AD-09-2001-128-8-9-0151-9638-101019-ART8

Gummow, B., 2003, 'A survey of zoonotic diseases contracted by South African veterinarians', Journal of the South African Veterinary Association 74(3), 72-76. http://dx.doi.org/10.4102/jsava.v74i3.514

Guo, J., Zhang, Z., Edwards, J.F., Ermel, R.W., Taylor, C. Jnr. \& De La Concha-Bermejillo, A., 2003, 'Characterization of a North American orf virus isolated from a goat with persistent, proliferative dermatitis', Virus Research 93, 169-179. http://dx.doi. persistent, proliferative dermatitis',
org/10.1016/S0168-1702(03)00095-9

Guo, J., Rasmussen, J., Wünschmann, A. \& De La Concha-Bermejillo, A., 2004, 'Genetic characterization of orf viruses isolated from various ruminant species of a zoo', Veterinary Microbiology 99, 81-92. http://dx.doi.org/10.1016/j. vetmic.2003.11.010

Haig, D.M. \& McInnes, C.J., 2002, 'Immunity and counter-immunity during infection with the parapoxvirus orf virus', Virus Research 88, 3-16. http://dx.doi. org/10.1016/S0168-1702(02)00117-X

Hautaniemi, M., Ueda, N., Tuimala, J., Mercer, A.A., Lahdenpera, J. \& McInnes, C.J., 2010, 'The genome of pseudocowpoxvirus: Comparison of a reindeer isolate and a reference strain', Journal of General Virology 91, 1560-1576. http://dx.doi. org/10.1099/vir.0.018374-0

Hosamani, M., Bhanuprakash, V., Scagliarini, A. \& Singh, R.K., 2006, 'Comparative sequence analysis of major envelope protein gene (B2L) of Indian orf viruses isolated from sheep and goats', Veterinary Microbiology 116, 317-324. http:// dx.doi.org/10.1016/j.vetmic.2006.04.028

Hosamani, M., Scagliarini, A., Bhanuprakash, V., Mclnnes, C.J. \& Singh, R.K., 2009 'Orf: An update on current research and future perspectives', Expert Reviews 7(7), 879-893. http://dx.doi.org/10.1586/eri.09.64 
Inoshima, Y., Morooka, A. \& Sentsui, H., 2000, 'Detection and diagnosis of parapoxvirus by the polymerase chain reaction', Journal of Virological Methods 84, 201-208. by the polymerase chain reaction', Journal of Viro
$\mathrm{http}: / / \mathrm{dx}$.doi.org/10.1016/S0166-0934(99)00144-5

Inoshima, Y., Murakami, K., Yokoyama, T. \& Sentsui, H., 2010, 'Spatial and temporal genetic homogeneity of orf viruses infecting Japanese serows (Capricornis crispus)', Journal of Veterinary Medical Science 72(6), 701-707. http://dx.doi. org/10.1292/jvms.09-0467, PMid:20124763

Jain, S.C., Jain, R., Sharma, R.A. \& Capasso, F., 1997, 'Pharmacological investigation of Cassia italica', Journal of Ethnopharmacology 58(2), 135-142. http://dx.doi. org/10.1016/S0378-8741(97)00091-3

Jones, D.T., Taylor, W.R. \& Thornton, J.M., 1992, 'The rapid generation of mutation data matrices from protein sequences', Computer Applications in the Biosciences 8, 275-282. http://dx.doi.org/10.1093/bioinformatics/8.3.275

Kazmi, M.H., Malik, A., Hameed, S., Akhtar, N. \& Ali, S.N., 1994, 'An anthraquinone derivative from Cassia italica', Phytochemistry 36(3), 761-763. http://dx.doi. org/10.1016/S0031-9422(00)89812-X

Kitching, R.P., 2004, 'Orf', in J.A.W. Coetzer \& R.C. Tustin (eds.), Infectious diseases of livestock, 2nd edn., vol. 2, pp. 1282-1286, Oxford University Press, Cape Town.

Klein, J. \& Tryland, M., 2005, 'Characterisation of parapoxviruses isolated from Norwegian semi-domesticated reindeer (Rangifer tarandus tarandus)', Virology 2 79. http://dx.doi.org/10.1186/1743-422X-2-79

Kummeneje, K. \& Krogsrud, J., 1979, 'Contagious ecthyma (orf) in reindeer (Rangifer tarandus tarandus)', Veterinary Record 105(3), 60-61. http://dx.doi.org/10.1136/ vr.105.3.60, PMid:576046

Lederman, E.R., Green, G.M., De Groot, H.E., Dahl, P., Goldman, E., Greer, P.W. et al., 2007, 'Progressive orf virus infection in a patient with lymphoma: Successful treatment using Imiquimod', Clinical Infectious Diseases 44(11), 100-103. http://dx.doi.org/10.1086/517509

Lewis, C., 1996, 'Update on orf', In Practice 18, 376-381. http://dx.doi.org/10.1136/ inpract.18.8.376

Lewis-Jones, S., 2004, 'Zoonotic poxvirus infections in humans', Current Opinion Infectious Diseases 17, 81-89. http://dx.doi.org/10.1097/00001432-20040400000003, PMid:15021045

Malan, S.W., 2000, 'The improved Boer goat', Small Ruminant Research 36(2), 165-170. http://dx.doi.org/10.1016/S0921-4488(99)00160-1

Masoko, P., Gololo, S., Mokgotho, P., Eloff, K., Howard, R. \& Mampur, L., 2010, 'Evaluation of the biological activities of the acetone extract of the roots of Senna italica', African Journal of Traditional, Complementary and Alternative Medicines 7(2), 138-148. http://dx.doi.org/10.4314/ajtcam.v7i2.50873

Mazur, C. \& Machado, R.D., 1989, 'Detection of contagious pustular dermatitis virus of goats in a severe outbreak', Veterinary Record 125, 419-420. http://dx.doi. org/10.1136/vr.125.16.419

McElroy, M.C. \& Bassett, H.F., 2007, 'The development of oral lesions in lambs naturally infected with orf virus', The Veterinary Journal 174, 663-664. http:// dx.doi.org/10.1016/j.tvjl.2006.10.024

Munz, E. \& Dumbell, K., 2004, 'Pseudocowpox', in J.A.W. Coetzer \& R.C. Tustin (eds.), Infectious diseases of livestock, 2nd edn., vol. 2, pp. 1689-1694, Oxford University Press, Cape Town.

Ndikuwera, J., Odiawo, G.O., Usenik, E.A., Kock, N.D., Ogaa, J.S. \& Kuiper, R., 1992 'Chronic contagious ecthyma and caseous lymphadenitis in two Boer goats', Veterinary Record 131, 584-585. http://dx.doi.org/10.1136/vr.131.25-26.584

Nettleton, P.F., Brebner, J., Pow, I., Gilray, J.A., Bell, G.D. \& Reid, H.W., 1996, 'Tissue culture-propagated orf virus vaccine protects lambs from orf virus challenge' Veterinary Record 138, 184-186. http://dx.doi.org/10.1136/vr.138.8.184

OIE. See World Organisation for Animal Health.

Perry, B.D., Randolph, T.F., McDermott, J.J., Sones, K.R. \& Thornton, P.K.M., 2002, 'Investing in animal health research to alleviate poverty', International Livestock Research Institute (ILRI), Nairobi.
Rodríguez, Y., Scagliarini, A., Alfonso, P., Ramírez, W., Elías, A., Antúnez, G. et al., 2011 'Risk factors correlated to orf in Guantanamo Province', Italian Journal of Tropical Medicine 16, 103-109.

Rogers, M., Bale, P., De Silva, L.M., Glasson, M.J. \& Collins, E., 1989, 'Giant parapox infection in a two year old child', The Australasian Journal of Dermatology 30(2), 87-91. http://dx.doi.org/10.1111/j.1440-0960.1989.tb00426.x

Rossiter, P.B. \& Taylor, W.P., 1994, 'Peste des pestis ruminants', in J.A.W. Coetzer \& R.C. Tustin (eds.), Infectious diseases of livestock, vol. 2, pp. 758-765, Oxford University Press, Cape Town.

Saitou, N. \& Nei, M., 1987, 'The neighbor-joining method: A new method for reconstructing phylogenetic trees', Molecular Biology and Evolution 4, 406-425. PMid:3447015

Scagliarini, A., Dal Pozzo, F., Gallina, L., Guercio, A., Vaccari, F. \& Battilani, M. et al., 2006, 'In vitro activity of VEGF-E produced by orf virus strains isolated from classical and severe persistent contagious ecthyma', Veterinary Microbiology 114 142-147. http://dx.doi.org/10.1016/j.vetmic.2005.11.052

Scagliarini, A., Vaccari, F., Turrini, F., Bianchi, A., Cordioli, P. \& Lavazza, A., 2011 'Parapoxvirus infections of red deer, Italy', Emerging Infectious Diseases 17, 684687. http://dx.doi.org/10.3201/eid1704.101454

Schmidt, E., Weissbrich, B., Bröcker, E.B., Fleischer, K., Goebeler, M. \& Stich, A., 2006 'Orf followed by erythema multiforme', Journal of the European Academy of Dermatology and Venereology 18,602-634. http://dx.doi.org/10.1111/j.1468Dermatology and Vene

Schoeman, S.J., Cloete, S.W.P. \& Olivier, J.J., 2010, 'Returns on investment in sheep and goat breeding in South Africa', Livestock Science 130, 70-82. http://dx.doi. org/10.1016/j.livsci.2010.02.012

Smith, G.W., Scherba, G., Constable, P.D., Hsiao, V., Behr, M.J. \& Morin, D.E., 2002, 'Atypical parapoxvirus infection in sheep', Journal of Veterinary Internal Medicine 16, 287-292. http://dx.doi.org/10.1111/j.1468-3083.2006.01496.x

Steinhart, B., 2005, 'Orf in humans: Dramatic but benign (case report)', Canadian Journal of Emergency Medicine 7(6), 417. PMid: 17355710

Sullivan, J.T., Mercer, A.A., Fleming, S.B. \& Robinson, A.J., 1994, 'Identification and characterization of an orf virus homologue of the vaccinia virus gene encoding the major envelope antigen p37K', Virology 202, 968-973. http://dx.doi.org/ 10.1006/viro.1994.1420

Tamura, K., Peterson, D., Peterson, N., Stecher, G., Nei, M. \& Kumar, S., 2011, 'MEGA5: Molecular evolutionary genetics analysis using maximum likelihood, evolutionary distance, and maximum parsimony methods', Molecular Biology and Evolution 28(10), 2731-2739. http://dx.doi.org/10.1093/molbev/msr121

Tikkanen, M.K., McInnes, C.J., Mercer, A.A., Büttner, M., Tuimala, J., Hirvelä-Koski, V. et al., 2004, 'Recent isolates of parapoxvirus of Finnish reindeer (Rangifer tarandus tarandus) are closely related to bovine pseudocowpox virus', Journal of Genera Virology 85, 1413-1418. http://dx.doi.org/10.1099/vir.0.79781-0

Uzel, M., Sasmaz, S., Bakaris, S., Cetinus, E., Bilgic, E., Karaoguz, A. et al., 2005, 'A viral infection of the hand commonly seen after the feast of sacrifice: Human orf (orf of the hand)', Epidemiology and Infection 133, 653-657. http://dx.doi.org/10.1017/ S0950268805003778, PMid:16050510

Watson, P., 2004, 'Differential diagnosis of oral lesions and FMD in sheep', In Practice 26, 182-191. http://dx.doi.org/10.1136/inpract.26.4.182

White, K.P., Zedek, D.C., White, W.L., Simpson, E.L., Hester, E., Morrison, L. et al., 2008, 'Orf-induced immunobullous disease: A distinct autoimmune blistering disorder', Journal of the American Academy of Dermatology 58(1), 49-55. http://dx.doi. Journal of the American Academy
org/10.1016/j.jaad.2007.08.029

World Organisation for Animal Health (OIE), 2010, viewed 12 June 2012, from http:// web.oie.int/wahis/public.php?page=country_population

Zheng, M., Liu, Q., Jin, N., Jiangang, G., Huang, X., Li, H. et al., 2007, 'A duplex PCR assay for simultaneous detection and differentiation of Capripoxvirus and Orf virus', Molecular and Cellular Probes 21, 276-281. http://dx.doi.org/10.1016/j. mcp.2007.01.005 